\title{
Late Tremadocian (Early Ordovician) reefs on the Yangtze Platform, South China, and their geobiological implications: a synthesis
}

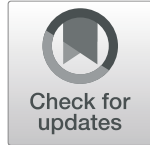

Jian-Po Wang ${ }^{1,2}$, Qi-Jian Li $i^{3,4^{*}}$, Stephen Kershaw ${ }^{5}$, Yuan-Yuan Zhang ${ }^{3,4}$, Shen-Yang Yu, $3,4,6$ and Yue Li,

\begin{abstract}
This study provides an overview and discussion of controls on the distribution of organic reefs during the Early Ordovican Period, in the Yangtze Platform, a region of epicontinental sedimentary rocks in South China. The Yangtze Platform was located in low latitudes during the Early Ordovician and recorded rich and diverse reefs through that time. During the late Tremadocian Epoch, dolomitic and stratiform stromatolites were common in supratidal to intertidal zones of the western Yangtze Platform, while columnar stromatolites formed in deeper waters of the eastern Yangtze Platform. Skeletal-dominated reefs occurred in upper subtidal settings of the central Yangtze Platform. A transition from microbial-dominated to metazoan-dominated reefs with shallowing-upward cycles was evident, indicating that the composition of the main reef-builders was driven mainly by water depth. Increasing metazoan competition during the Great Ordovician Biodiversification Event reduced the abundance of microbial reefs. Sufficient nutrient supply is interpreted to have promoted development of skeletal-dominated reefs locally in shallow settings in the central Yangtze Platform, especially represented by the expansion of abundant solitary fossils of lithistid sponges and Calathium. High salinity environmental settings facilitated the bloom of stromatolites in near-shore locations. Low oxygen content in deep subtidal settings may have led to the absence of skeletal reefs in these habitats, so the mass occurrences of stromatolites was located in the shallower-water central and eastern platform. No keratose sponge-bearing stromatolite can be confirmed across the platform during this interval.
\end{abstract}

Keywords: Reef succession, Spatial distribution, Late Tremadocian, Early Ordovician, Yangtze Platform, South China Block

\section{Introduction}

After the demise of archaeocyaths at the end of the Early Cambrian, Laurentia and Gondwana recorded an initial rebound of skeletal reef-builders during middle Cambrian time, characterized by lithistid sponge-bearing reefs (Lee and Riding 2018). Metazoan-dominated reefs expanded in the Early Ordovician Period, with the rise

\footnotetext{
* Correspondence: qji@@nigpas.ac.cn; qijianli@hotmail.com

${ }^{3}$ State Key Laboratory of Palaeobiology and Stratigraphy, Nanjing Institute of Geology and Palaeontology, Chinese Academy of Sciences, Nanjing 210008, Jiangsu Province, China

${ }^{4}$ Center for Excellence in Life and Paleoenvironment, Chinese Academy of Sciences, Nanjing 210008, Jiangsu Province, China

Full list of author information is available at the end of the article
}

of Calathium, Pulchrilamina, bryozoans, Lichenaria and other reef-builders (Webby 2002; Servais et al. 2010; Servais and Harper 2018) in West Laurentia (Toomey and Nitecki 1979), Laurentia-derived Argentinian Precordillera (Lehnert et al. 1998; Carrera et al. 2017), Yangtze Platform (Wang et al. 2012) and Taebaeksan Basin (Kwon et al. 2003; Choh et al. 2013). Appearance of encrusting-domical forms (e.g. bryozoans Nekhorosheviella) progressively transformed reef structures (Kröger et al. 2017) and facilitated the subsequent expansion of coral-stromatoporoid-bryozoan reefs in the Upper Ordovician (Webby 2002). However, microbialites still 
dominated Early Ordovician reef ecosystems in terms of abundance (Webby 2002; Pratt 1995; Peters et al. 2017).

In the last decade, much progress has been achieved in understanding the nature and environments of Early Ordovician reefs on the Yangtze Platform of South China Block (e.g., Adachi et al. 2012a; Li et al. 2015, 2017). Early Tremadocian reefs on the Yangtze Platform are characterized by microbialites with low abundance of lithistid sponges and Calathium (Wang et al. 2012; Zhang et al. 2016). The oldest bryozoan reefs occurred in the late Tremadocian; while microbialites and bryozoan reefs dramatically declined with the expansion of hypercalcified sponges (e.g., Calathium, Pulchrilamina) on the platform during the Floian (Zhu et al. 2006; Adachi et al. 2011, 2012a, 2013; Xiao et al. 2011; Zhang et al. 2016; Li et al. 2017). Thus, the late Tremadocian reefs on the Yangtze Platform showcase one of the most diverse shallow marine ecosystems in the world at that time ( $\mathrm{Li}$ et al. 2004; Zhu et al. 2006; Xiao et al. 2011; Adachi et al. 2011, 2013; Wang et al. 2012; Li et al. 2015).

It has been proposed that variation of water depth, bioturbation (Liu 2009; Liu and Zhan 2009), temperature (Trotter et al. 2008), oxygen level (Edwards et al. 2017) and nutrient conditions (Martin 1995, 1996) may have had strong influence on reef developments during the Early Ordovician. In this paper, we re-examine the late Tremadocian reefs on the Yangtze Platform. Based on published data and our own collections, we discuss how environmental factors affected the spatial differentiations, which provide insight into the paleoecology of Early Ordovician reefs and their geobiological implications. We therefore aim to provide an overview of the depositional settings and environmental controls on the development of Early Ordovician reefs on the Yangtze Platform.

\section{Geological setting}

South China Block was interpreted to be dominated by a low-gradient basinward epeiric platform (Yangtze Platform) (Torsvik and Cocks 2013), deepening from shallow areas in the west towards the southeastern Jiangnan Slope and Zhujiang Basin during the Early Ordovician (Li et al. 2004) (Fig. 1). Except for localized input of terrigenous sediments in the western and northwestern near-shore belts, most of the Yangtze Platform is carbonate-dominated (Chen et al. 1995; Zhan and Jin 2007). Gradual transgression from the beginning of the Ordovician triggered a lithological changeover from the dolostone-dominated Furongian (Series 4 of the Cambrian) to the limestone-dominated Tremadocian Series (Zhang et al. 2016). The reef-bearing units of the late Tremadocian Tungtzu (or Tongzi), Fenhsiang (or Fenxiang) and Lunshan formations are arranged approximately from west to east, shown in Fig. 2.

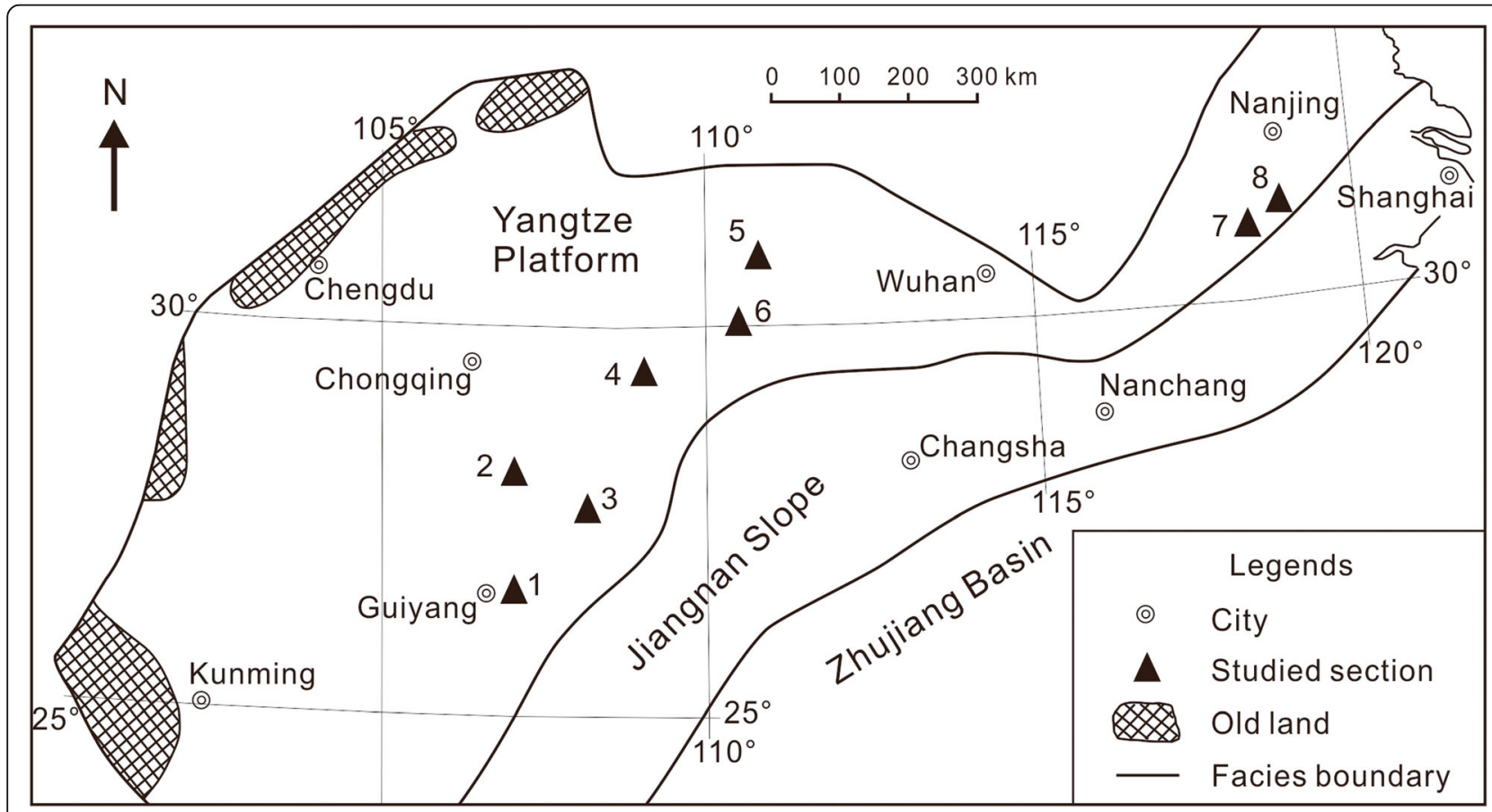

Fig. 1 Localities of the late Tremadocian reef sections of South China (modified from Zhan and Jin 2007). Note that three sections from western Yangtze Platform: Wudang (section 1), Kuaizishan (section 2) and Honghuayuan (section 3) sections in Guizhou Province; three sections from central Yangtze Platform: Taiping (section 4), Huanghuachang (section 5) and Liujiachang (section 6) sections in the Three Gorges Area; and two sections from eastern Yangtze Platform: Shitai (section 7) and Beigong (section 8) sections in Anhui Province 


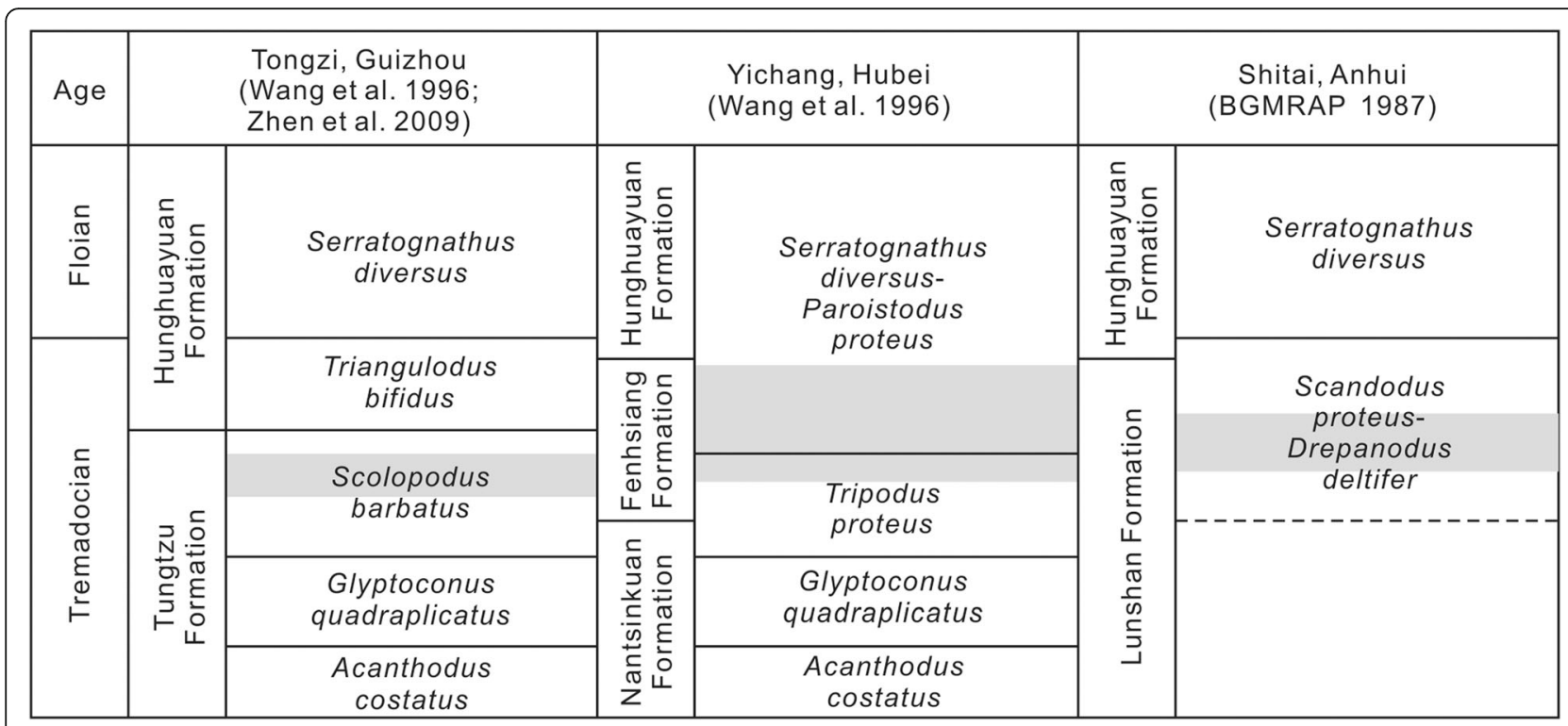

Fig. 2 Correlation chart showing typical Lower Ordovician lithostratigraphic units on the Yangtze Platform. Shadows show the late Tremadocian reef horizons. BGMRAP = Bureau of Geology and Mineral Resources of Anhui Province

Tungtzu Formation is confined to a very shallow belt covering the main part of the western Yangtze Platform; coeval shales of the Luohanpo and Tangchi formations occur along the westernmost near-shore belts (Zhan and Jin 2007). Contemporary reef-bearing units to the east are the Nantsinkuan and Fenhsiang formations in ascending order, which comprise offshore facies in the central platform region, and the Lunshan Formation in eastern Yangtze Platform, representing another offshore area (Li et al. 2004). The overlying Hunghuayuan Formation (latest Tremadocian to early Floian) with fossil-rich bioclastic limestones developed almost synchronously across the most part of Yangtze Platform, although its base is stratigraphically slightly older in the western platform than elsewhere (Zhen et al. 2009).

Lithological sequences of the Tungtzu Formation are characterized by medium- to thick-bedded dolomites and bioclastic limestones intercalated with pebble, oolitic and oncolitic dolomites, and shale interbeds are common in the top and lower part (Zhan and Jin 2007). Wang et al. (1996) reported Tremadocian conodont biozonations of Acanthodus costatus, Glyptoconus quadraplicatus, and Scolopodus barbatus in ascending order. Fenhsiang Formation is composed of medium-bedded bioclastic and oolitic packstones in the lower part; and thin- to thick-bedded bioclastic limestones rich in crinoidal and brachiopodal fragments with less shales in the upper part. Wang et al. (1987) dated the sequence as belonging to the Tripodus proteus (=Paltodus deltifer) conodont biozone, and the top reaches the Paroistodus proteus conodont biozone. Lithologies in the Lunshan Formation change from dolomite-dominated facies in the lower part to thick-bedded micritic limestonedominated strata with stromatolites (tens of meters thick) in the upper part. The Drepanodus deltifer-Scandodus proteus conodont biozone in the upper part of the Lunshan Formation (BGMRAP 1987) is equivalent to the Tripodus proteus biozone of the Fenhsiang Formation (Fig. 2).

\section{Results}

\subsection{Spatial distribution and succession of the late Tremadocian reefs}

Late Tremadocian reefs are abundant in the central platform, but they are relatively rare in the western and eastern part of the Yangtze Platform. Eight reef-bearing sections are used to illustrate facies differentiation: 1) western platform: Wudang, Kuaizishan and Honghuayuan sections in Guizhou Province; 2) central platform: Taiping, Huanghuachang and Liujiachang sections in the Three Gorges Area; and, 3) eastern platform: Shitai and Beigong sections in Anhui Province (see Fig. 1). Lithology and reef horizons of these sections are shown in Figs. 3 and 4.

\subsubsection{Western platform}

Late Tremadocian stromatolites occur mostly near the top of the Tungtzu Formation in the western platform. The stromatolites in the Wudang section are $40 \mathrm{~cm}$ thick and flat column shaped, but strongly dolomitized (Figs. 3, 5a). Stromatolite laminae are recognizable in outcrop due to surface weathering (Fig. 5a, b), but are not visible in thin sections. The reef is covered by wellbedded dolostones. In contrast to the reefs of the 


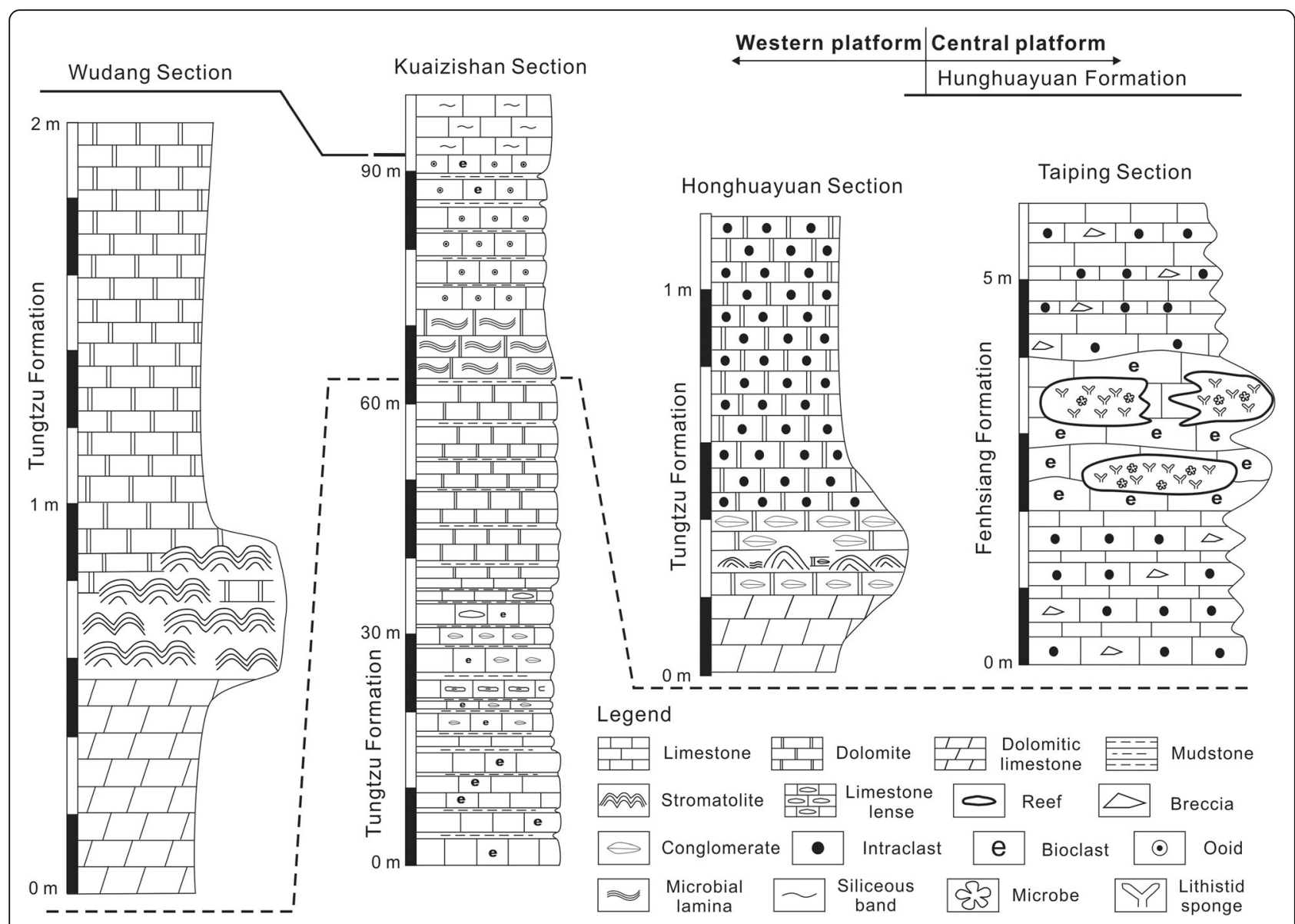

Fig. 3 Lithological columns of the sections on the western and central Yangtze Platform (1-4 sections in Fig. 1) showing palaeogeographic locations and approximate correlation of the reef-bearing strata

Wudang section, the laminar stromatolites in two layers of $1.5 \mathrm{~m}$ and $2 \mathrm{~m}$ in thickness at the Honghuayuan section (Fig. 5c, d) are both dolomitized (Zhang et al. 2016) and are covered by oolitic limestones (Fig. $5 \mathrm{c}$, d). At the Kuaizishan section, small low dome-shaped stromatolites (Fig. 5e) are surrounded by flat-pebble beds and thinbedded grainstones (Fig. 5f), indicating a wave/stormdominated carbonate tidal setting (Myrow et al. 2004).

\subsubsection{Central platform}

As the first occurrence of the metazoan-bearing reefs in the Yangtze Platform, Calathium-lithistid spongemicrobial and bryozoan reefs were reported respectively in the early Tremadocian Nantsinkuan Formation in Wentang, Hunan Province (Wang et al. 2012; Zhang et al. 2016) and Liujiachang, Hunan Province (Cuffey et al. 2013). Small-scale reefs expanded in the late Tremadocian Fenhsiang Formation, with various metazoan builders throughout the central platform. Five types had been distinguished: lithistid sponge-microbial, lithistid sponge-bryozoan, bryozoan, lithistid sponge-Calathiummicrobial reefs and stromatolites (Zhu et al. 2006; Xiao et al. 2011; Wang et al. 2012; Adachi et al. 2013; Zhang et al. 2016). Although small in size (mostly $1-5 \mathrm{~m}$ in length and $0.3-2 \mathrm{~m}$ in height), such reefs are quite common in the central part of the Yangtze Platform, especially in the Three Gorges Area. The shapes of those reefs vary from lenticular to irregular dome-shaped.

Apart from the bryozoan reefs in the Liujiachang section, lithistid sponge-microbial reefs are widespread in the Three Gorges Area, as pioneer communities. The reefs in the Huanghuachang and Taiping sections grew on skeletal hard grounds (Fig. 6a, b), or unconsolidated sediments (Fig. 6e), and the reef cores are dominated by sponge bafflestones (Fig. 6c) with a few crinoids (holdfasts) (Fig. 6d). Encrustations of microbes were common with laminar texture in most cases (Fig. 6 c, d, Fig. 7 a), and Girvanella appears uncommonly (Fig. 7b, c). Adachi et al. (2013) also reported small stromatolites in one of the lithistid sponge-microbial reefs in the Fenhsiang Formation at the Chenjiahe section, which is close to the Huanghuachang site.

The oldest bryozoan Prophyllodictya simplex was discovered from the Nantsinkuan Formation by Ma et al. 


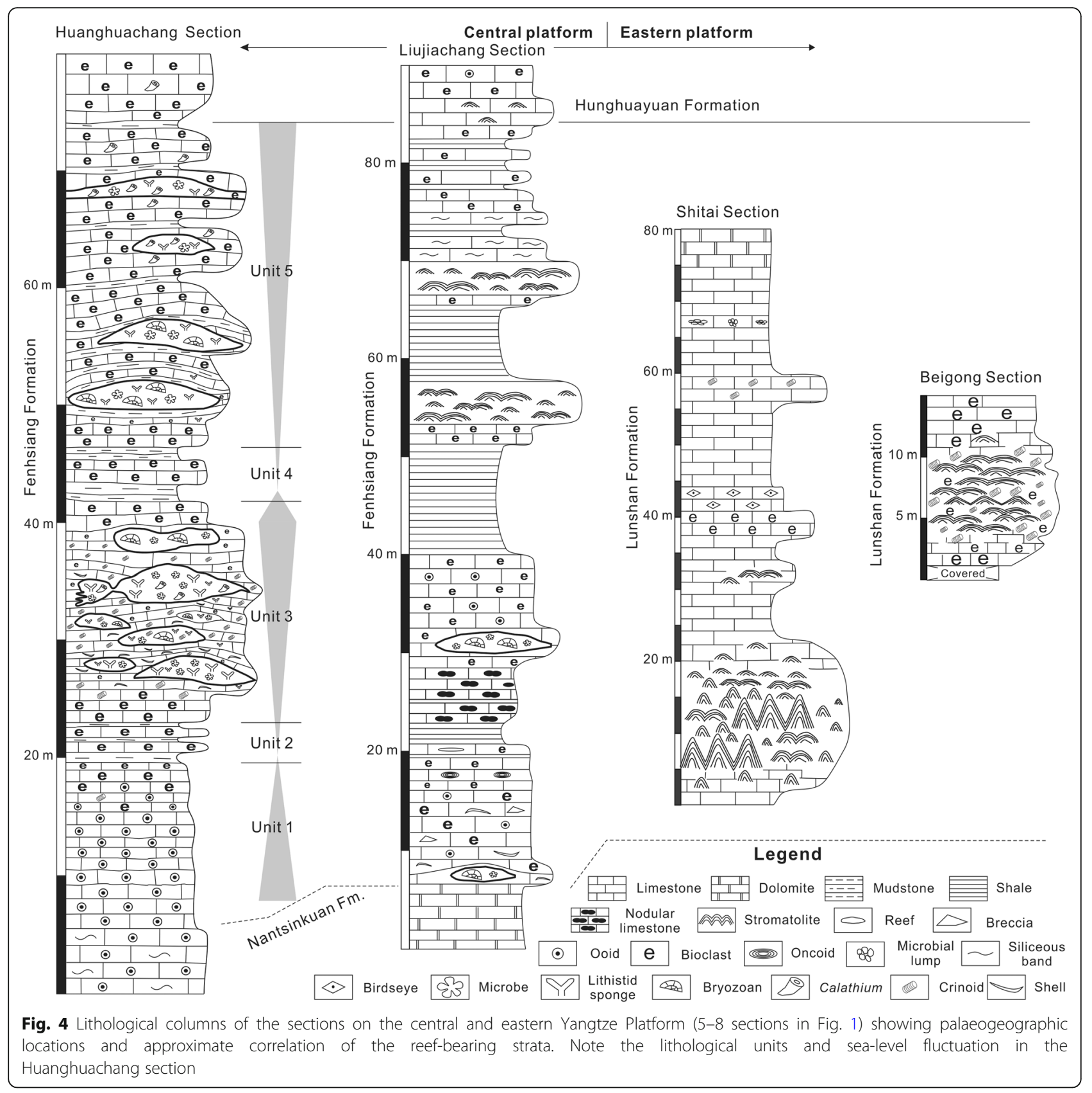

(2015) at the Liujiachang section, but it is not a reefbuilder. In contrast, the colonial and encrusting Nekhorosheviella was the main framework builder of the oldest bryozoan reefs in the Fenhsiang Formation (Adachi et al. 2012a). In the Huanghuachang and Liujiachang sections, bryozoans show two different growth patterns in reefs: 1) lithistid sponges firstly settled on the skeletal substrate acting as framebuilders, then bryozoans encrusted the sponges with downward growth, forming a lithistid sponge-bryozoan reef (Fig. 8a, c, e); and, 2) stacked bryozoans directly grew on the skeletal hard ground to develop bryozoan reefs (Fig. 8b, d, f). Adachi et al. (2013) also reported that bryozoans used pelmatozoans as scaffolds to build a skeletal framework in the Fenhsiang Formation at Chenjiahe, similar to the growth pattern of the lithistid sponge-bryozoan reefs. Also, the hypercalcified sponge Pulchrilamina was found in the reefs in the Fenhsiang Formation, encrusting lithistid sponges and bryozoans (Zhu et al. 1993; Adachi et al. 2012b).

As a baffler, Calathium played a minor role in the community when it first occurred in the Calathiumlithistid sponge-microbial reef in Unit 3 of the Fenhsiang Formation in the Huanghuachang section (Fig. 4). On average, Calathium occupied less than $5 \%$ of the reefs. 

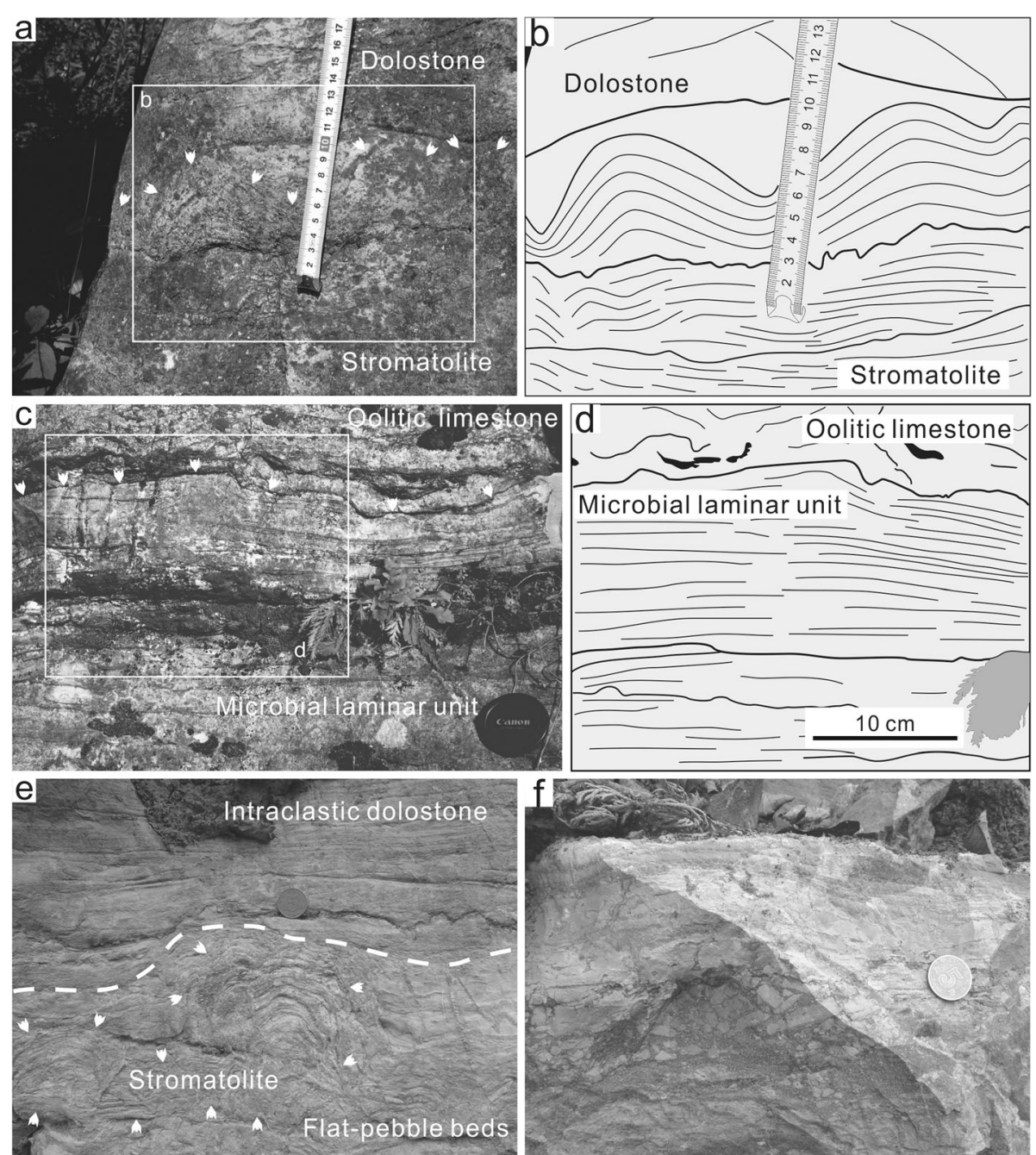

Fig. 5 Photographs of microbial reef units from sections on the western Yangtze Platform. a Field view of the Wudang stromatolite covered by dolomite; $\mathbf{b}$ Sketch of the box part in a showing the outline of the laminae in stromatolites; $\mathbf{c}$ Field view of the Honghuayuan microbial lamina covered by oolitic limestone. The diameter of lens cap $=67 \mathrm{~mm}$; d Sketch of the box part in c showing the details of the microbial laminae; e Profile view of stromatolite at Kuaizishan section; f A well-weathered rock surface of Kuaizishan section, revealing the flat-pebble beds. The coin diameter $=2 \mathrm{~cm}$

In terms of reef construction, however, the Calathiumlithistid sponge-microbial reef is not much different from the lithistid sponge-microbial reef, except for the occurrence of Calathium. Calathium became a main reef-builder in the lithistid sponge-Calathium-microbial reefs nearing the boundary between the Fenhsiang and Hunghuayuan formations. These reefs are surrounded by shale (Fig. 9a) and are characterized by occurrences of rich Calathium (making up 20\%-30\%) and a few lithistid sponges (about 5\%) (Fig. 9b). Calathids and lithistid sponges encrusted upon each other (Fig. 7d) in some cases.

The stromatolites of the upper Fenhsiang Formation in the Liujiachang section are rare (Fig. 4), but they represent one of a few microbial reefs in the central platform (Adachi et al. 2013). The stromatolite-bearing beds of up to 5 -m-thick are surrounded by 10 -m-thick shales interbedded with thick-bedded bioclastic limestones (Fig. 9c, d). Cross-bedded limestones are distinct in the outcrop, suggesting a high energy environment.

\subsubsection{Eastern platform}

Stromatolites of the Lunshan Formation in the Shitai section, Anhui Province, were firstly reported by Li et al. (2004), and were subsequently re-measured and described by Jiang et al. (2014). The stromatolites are about $23 \mathrm{~m}$ thick, with columnar to conical shapes (Fig. 10). The reefs are sporadic in the outcrops, with relatively higher abundance in the lower and middle parts. Macrofossils are rare in the reef, including sparse 

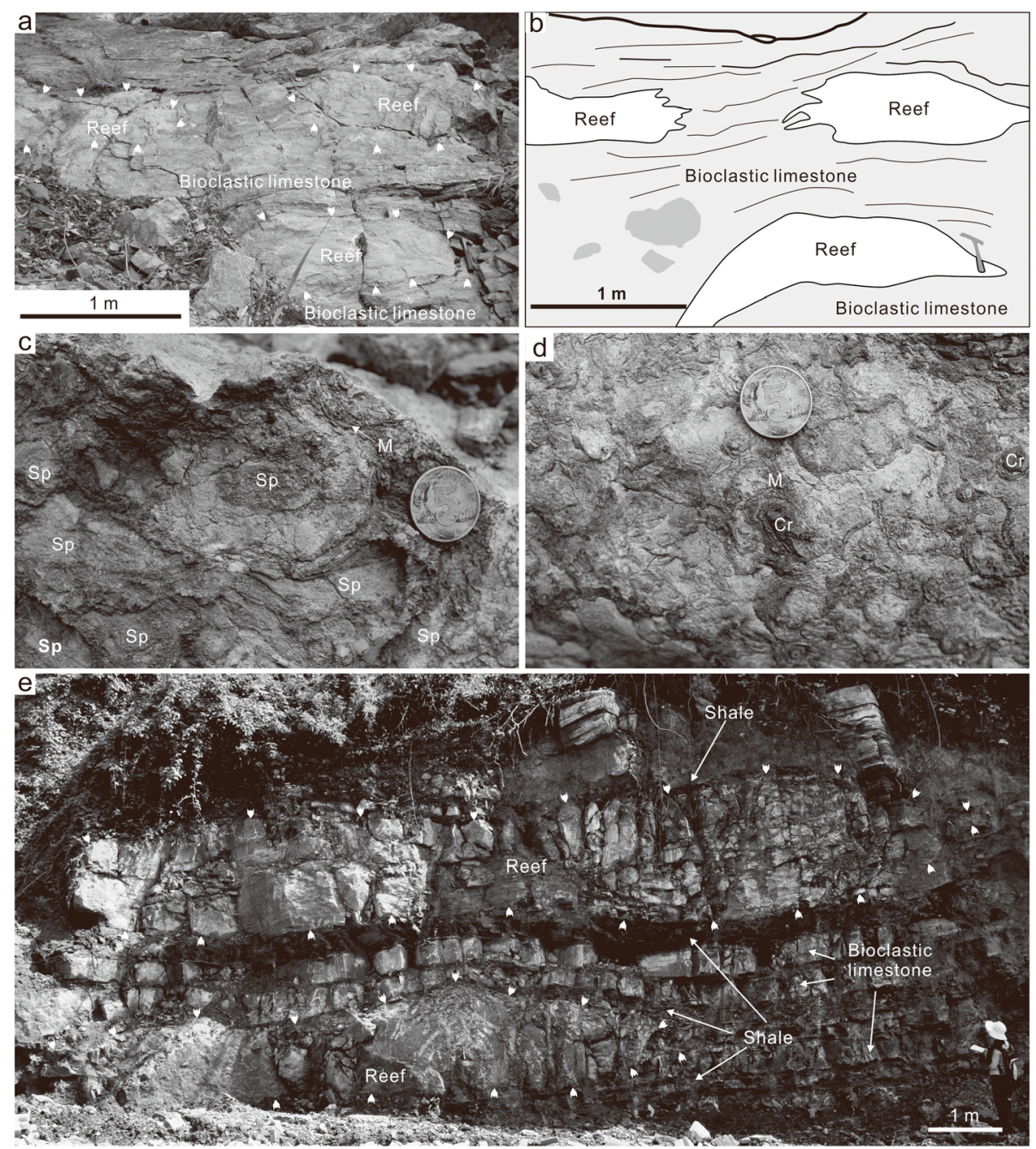

Fig. 6 Field photos of lithistid sponge-microbial reefs in the Taiping and Huanghuachang sections. a Field view of the Taiping reefs surrounded by bioclastic limestones; b Sketch of panel a showing the outline of the lithistid sponge-microbial reefs; c Details of Huanghuachang reefs showing lithistid sponges (Sp) encrusted by microbes (M); d Microbes (M) encrusting crinoid holdfasts (Cr) in the reefs of Huanghuachang section. The coin diameter $=2 \mathrm{~cm}$; e Field view of the Huanghuachang reefs showing the surrounding bioclastic limestone and shale

nautiloids, trilobites and crinoids in the space between stromatolitic columns. However, organic burrows commonly disturbed the laminae of the stromatolites. The top of the stromatolites is capped by bioclastic limestones. In contrast, the stromatolites of the Lunshan Formation in the Beigong section, Jiangxi Province, are characterized by stratiform and dome-shaped laminations (Fig. 11a, c). Girvanella filaments are ubiquitous in thin sections (Fig. 11b, d). Crinoids grew on the surfaces of the microbialites (Yu et al. 2020).

\subsection{Summary of reef pattern and water depth correlation} The spatial distribution of late Tremadocian reefs shows the occurrence of stromatolites throughout the Yangtze Platform, however skeletal reefs occur only in the central platform (Fig. 12). Centimeter-scale stromatolites also occur in those skeletal reefs, which may have developed in upper subtidal zones based on faunal and depositional characters in the Huanghuachang section (Chen and Qiu 1986). The skeletal reefs at Taiping and Liujiachang sections shared similar habitats of shallow subtidal environment. Stromatolites tend to be better developed in intertidal and deep subtidal settings. Evaporative and high salinity settings were recorded in the stromatolites in the western platform (Wang et al. 2012). In contrast, the high aspect ratio of the stromatolites and associated fine-grained clastics are consistent with deep subtidal habitats, which might be deeper than fair-weather wave base (Grotzinger 1989). There is no evidence of any keratose sponge-bearing (e.g. Li et al. 2017) stromatolite on the platform during this time. 

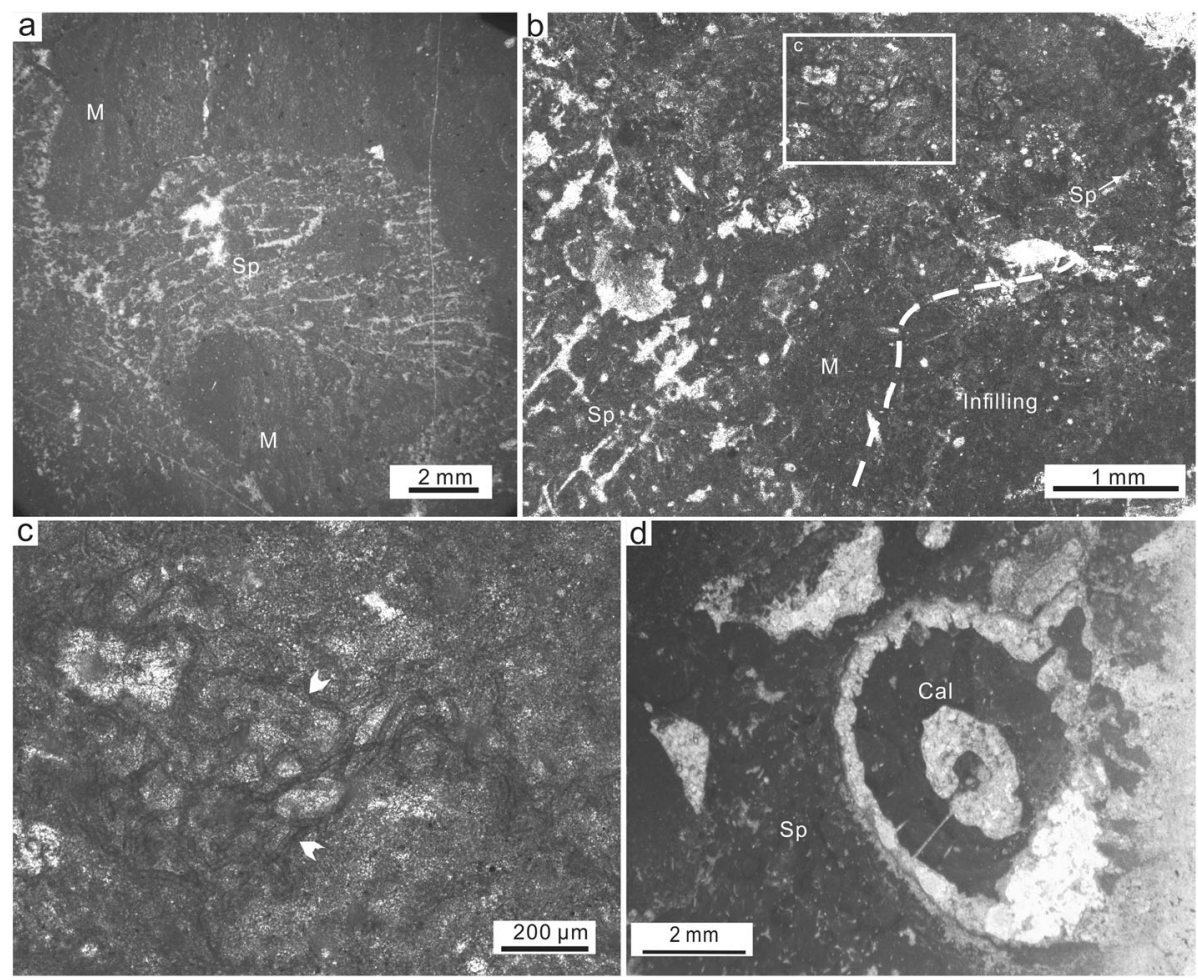

Fig. 7 Photomicrographs of the lithistid sponge-microbial reefs in the Taiping and Huanghuachang sections. a Photomicrograph of the reefs in Taiping section, showing lithistid sponges (Sp) surrounded by microbial fabrics (M); b Photomicrograph of the reefs in the Huanghuachang section; note lithistid sponges (Sp) and microbial fabric (M) bounded with (dashed line) the infilling; c Detail of the box part in $\mathbf{b}$ showing filaments of Girvanella (as indicated by arrow heads); $\mathbf{d}$ Photomicrograph showing Calathium (Cal) and lithistid sponge (Sp) attached each other in the Huanghuachang reef

During late Tremadocian, the reef successions in the central platform were driven mainly by sea level fluctuation (Zhu et al. 2006; Xiao et al. 2011): lithistid spongemicrobial reefs were replaced by bryozoan reefs or lithistid sponge-Calathium-microbial reefs in shallowing upward cycles in the Unit 3 and Unit 5 of Huanghuachang section. Transition from lithistid sponge-bryozoan reefs to stromatolites in the Liujiachang section is attributed to increasing water depth, due to the reduction of metazoan builders and rise of microbialites. Overall, in terms of faunal composition, the waxing and waning of reef communities on the Yangtze Platform indicate that different reef types had different construction ability in relation to water depth (Fig. 13).

\section{Discussion: geobiological implications for Early Ordovician reef systems}

According to Webby (2002) and new data from Early Ordovician strata (e.g., Federov 2003; Adachi et al. 2009; Choh et al. 2013; Li et al. 2019), some sixty reefs are recorded globally. Almost 70\% of them are microbial reefs and only four cases are colonial skeletal reefs (Toomey 1970; Toomey and Nitecki 1979; Adachi et al. 2009; Cuffey et al. 2013). The distribution and characters of the reefs in South China are consistent with those in some other areas of the world. In southeastern USA, supratidal stromatolites occurred in the lower Ordovician Jefferson City Dolomite in the Missouri River floodplain (Ethington 1977), while subtidal microbial-lithistid sponge-Calathium reefs were found in the Mckelligon Canyon Formation in West Texas and the Kindblade Formation of Oklahoma (Toomey and Nitecki 1979). In northern Canada and Greenland, thriving microbial reefs were characterized by their occurrence in restricted inner shelf to outer shelf positions, whereas a few lithistid sponges encrusted stromatolites occurred in the outer shelf (de Freitas and Mayr 1995). Microbiallithistid sponge-Calathium reefs mostly occurred in subtidal settings in Korea and in Utah of USA (Hintze 1973; Church 1974; Choh et al. 2013).

With mat colonization reducing through time by metazoan grazing and competition for space on the shallow seafloor (Riding 2006; Fischer 1965), increasing bioturbation during the Great Ordovician Biodiversification Event (Liu 2009; Liu and Zhan 2009) altered primary microbialite fabrics, leading to the survival of stromatolites mainly in low bioturbation settings. The observed ecological antagonism between stromatolites and benthic 

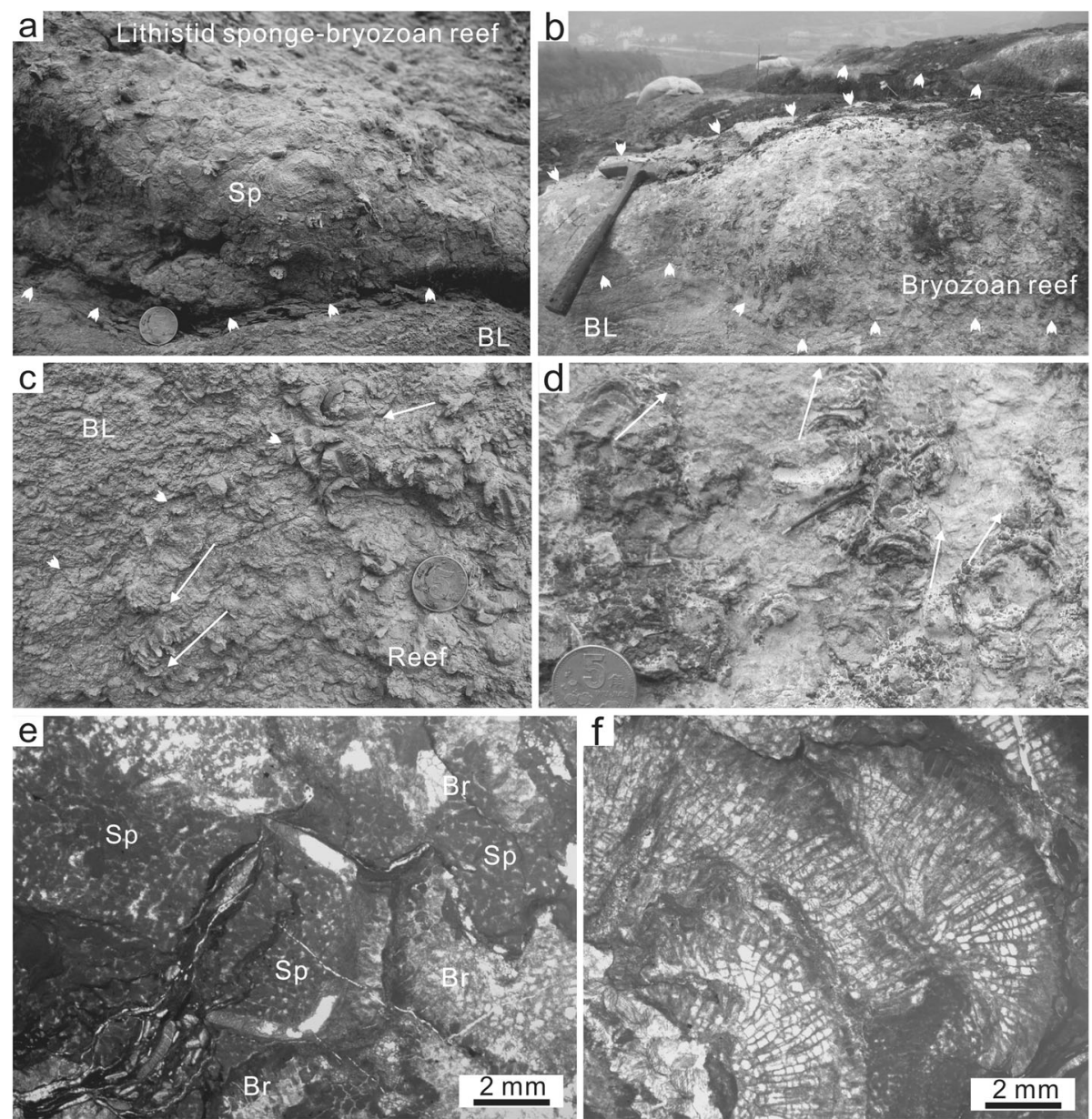

Fig. 8 Growth styles of the bryozoan reefs in the Huanghuachang section. a Lithistid sponge-bryozoan reefs, showing lithistid sponges (Sp) occurred firstly on the bioclastic limestones (BL) (arrow heads showing the bottom of the reef); $\mathbf{b}$ Bryozoan reefs, showing bryozoans developed directly on the bioclastic limestones (BL); c Close-up of the lithistid sponge-bryozoan reefs, showing the downwards growth of bryozoans (arrows showing the outline of the reef); $\mathbf{d}$ Close-up of the bryozoan reefs, showing the upward growth of bryozoans (arrows); e Photomicrograph of lithistid sponge-bryozoan reef, showing bryozoans (Br) encrusted on the lithistid sponges (Sp); f Photomicrograph of bryozoan reefs showing zooidal chambers of bryozoans. The coin diameter $=2 \mathrm{~cm}$; The hammer length $=282 \mathrm{~mm}$

animals on the Yangtze Platform is consistent with this hypothesis. Cluster growth of the solitary skeletal reefbuilders, such as lithistid sponges and Calathium, would provide habitats for growth of reefal microbial carbonates to avoid predation (Forsythe 2003; Mallela 2007); they also provided hard substrates and shelters (e.g. cavities) which further promoted the diversification of reef communities on the Yangtze Platform (Li et al. 2017).

Biomass of animals is interpreted to have increased during the Ordovician (Payne and Finnegan 2006), a view supported by the sustained growth of skeletal components in Tremadocian reefs as we show above. The available habitat area expanded in the epeiric sea of the Yangtze Platform as sea level rose (Chen et al. 1995; Zhu et al. 2006; Xiao et al. 2011). Lithistid sponges and Calathium likely preferred eutrophic or rich nutrient environments (Church 2009, 2017), contrasting with modern nutrient-independent scleractinian corals (Wood 1993). In addition, bryozoan-rich deposits may have been promoted by high trophic levels in the Ordovician (Taylor and Sendino 2010). Although the Cambrian-Ordovician seas have been demonstrated in extremely low nutrient conditions (e.g. Martin 1995, 1996; Servais et al. 2010), metazoan reef-builders gradually returned in nutrient-rich habitats interpreted with the sea level rise on the platform during late Tremadocian.

The scarcity of metazoan reefs in the western Yangtze Platform may be related to evaporative and high salinity conditions (Wang et al. 2012) in the nearshore areas, in an arid climate (Boucot et al. 2009) influenced by high temperatures (Fischer 1984; Trotter et al. 2008). Similar cases were reported in the Jefferson City Dolomite with abundant stromatolites (Ethington 1977). In addition, 

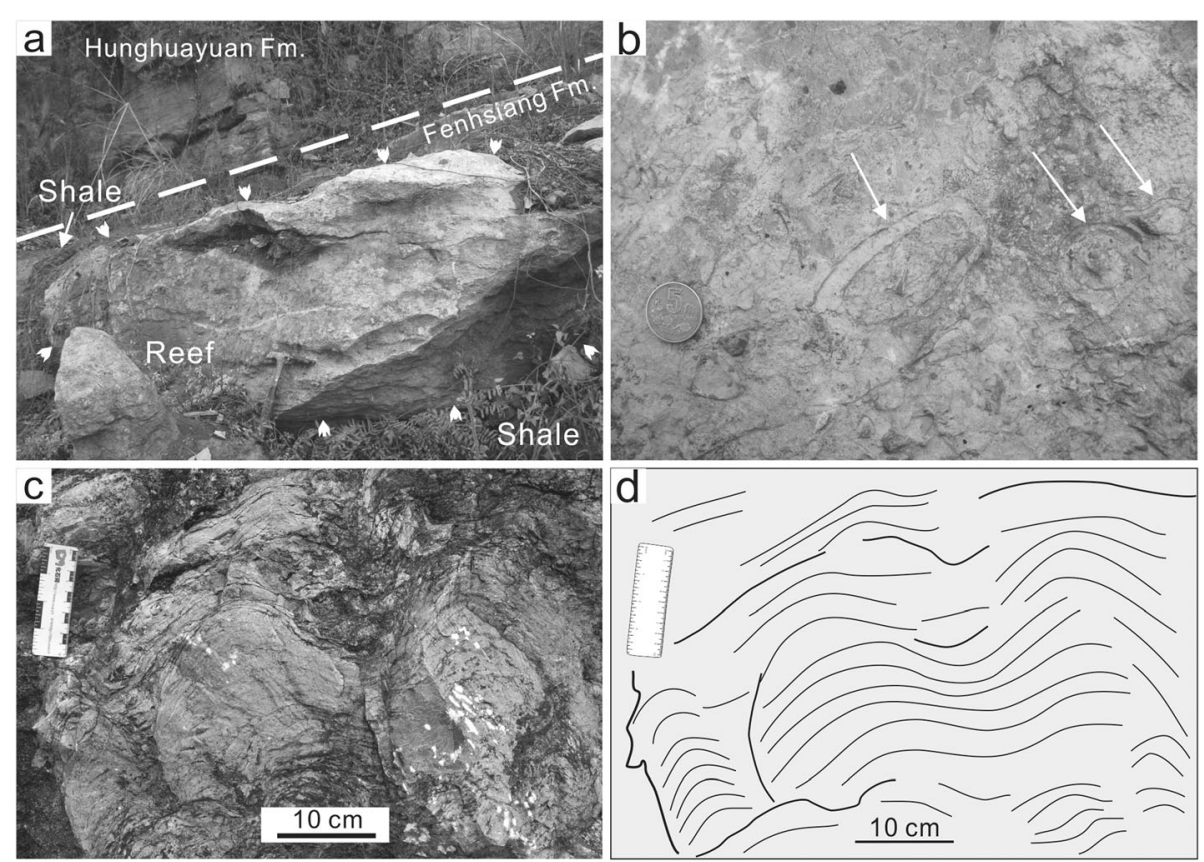

Fig. 9 Field views and photographs of the lithistid sponge-Calathium reefs in the Huanghuachang section (a, b) and stromatolites in the Liujiachang section (c, d). a Cross-sectional view of the reef, near the boundary (dashed line) between the Fenhsiang Formation and the Hunghuayuan Formation, surrounded by shale; $\mathbf{b}$ Top surface of the reef in $\mathbf{a}$, arrows indicate cluster growth of the Calathium; c Dome-shaped stromatolites in the Liujiachang section; $\mathbf{d}$ Sketch of panel $\mathbf{c}$ showing the outline of the laminae in stromatolites
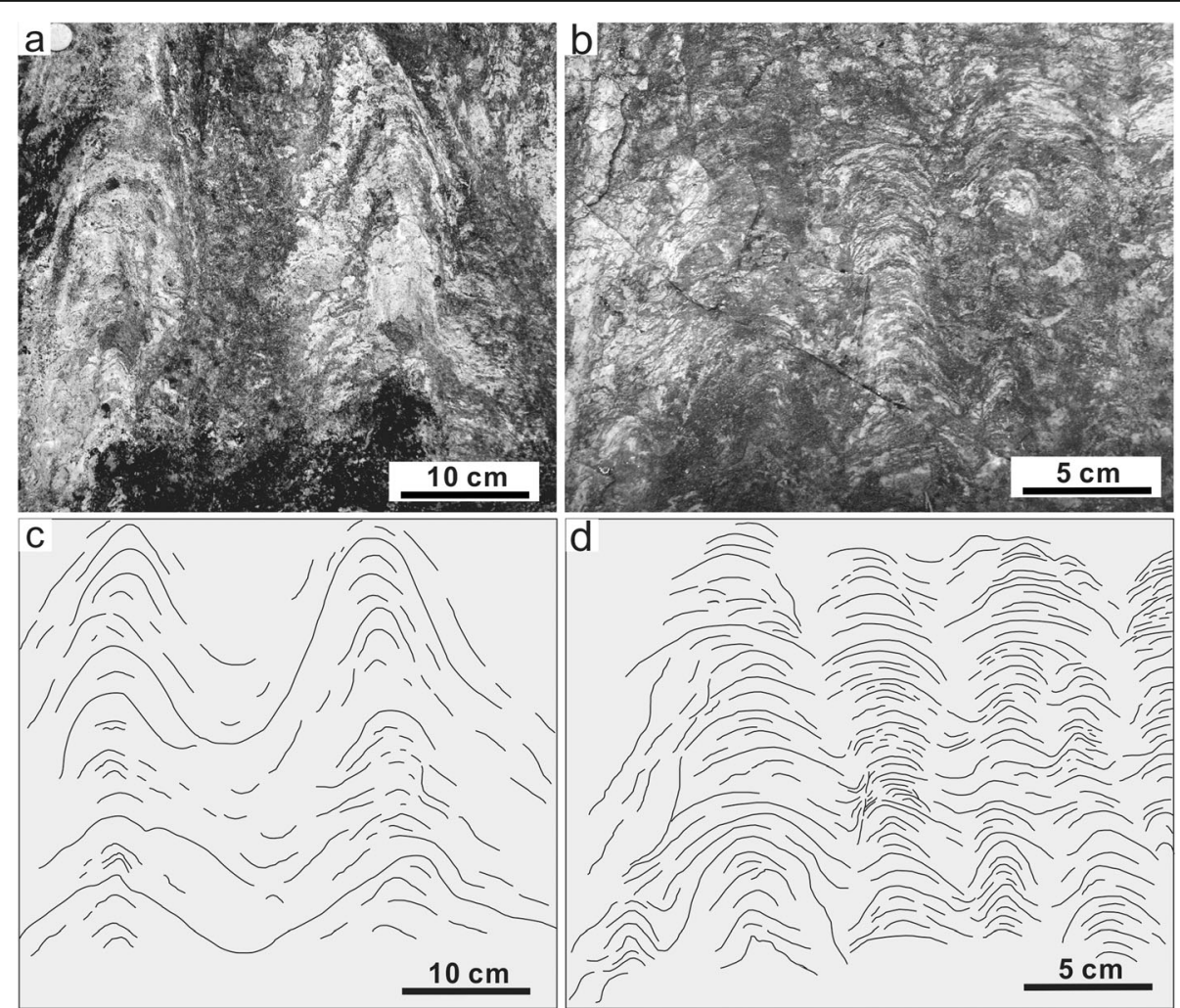

Fig. 10 Photographs for the stromatolites of the Lunshan Formation in the Shitai section, Anhui Province. a Conical-shaped columns from the lower part of the stromatolite; $\mathbf{b}$ Weathered columns from the upper part of the stromatolite; $\mathbf{c}$ Sketch of panel $\mathbf{a}$ showing the outline of the laminae in stromatolites; $\mathbf{d}$ Sketch of panel $\mathbf{b}$ showing the outline of the laminae in stromatolites 

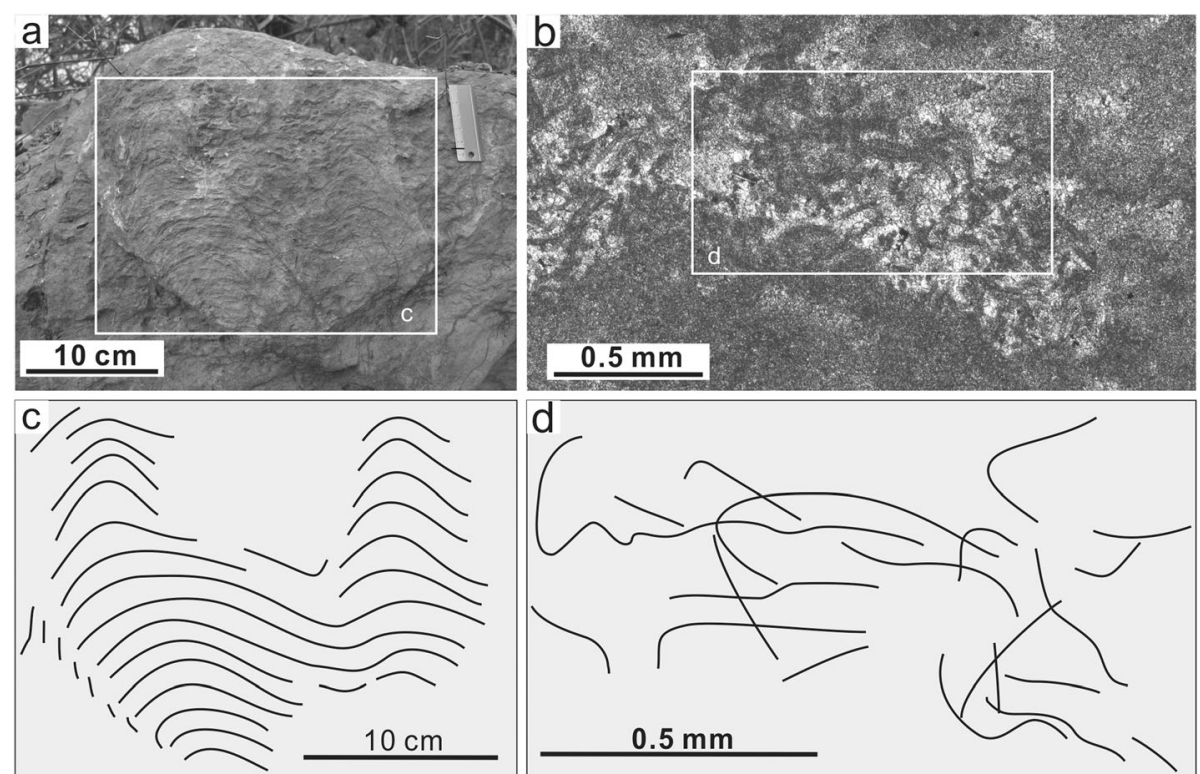

Fig. 11 Photographs for the stromatolites of the Lunshan Formation in the Beigong section, Jiangxi Province. a Profile view of the dome-shaped stromatolites in outcrop; b Microfacies of the stromatolitic units showing tangled filaments of Girvanella; $\mathbf{c}$ Sketch of panel $\mathbf{a}$ showing the outline of the laminae in stromatolites; $\mathbf{d}$ Sketch of panel $\mathbf{b}$ showing the filaments of Girvanella

various microbial reefs were recorded in the Early Ordovician evaporites from North and South Laurentia, and Siberia (Witzke 1990; Boucot et al. 2009).

In the Liujiachang and Shitai sections, stromatolites in deep subtidal settings might have suffered from hypoxia. With the sea-level rise, decreasing oxygen content was indicated by the Ce anomalies of conodont apatite from the Huanghuachang section, and the Unit 4 of the Fenhsiang Formation even showed anoxic conditions (Chen et al. 2012). Thick yellow-green shales in the Liujiachang section and scarce metazoan fossils in the Shitai section both indicate a similar redox condition to the Unit 4 of

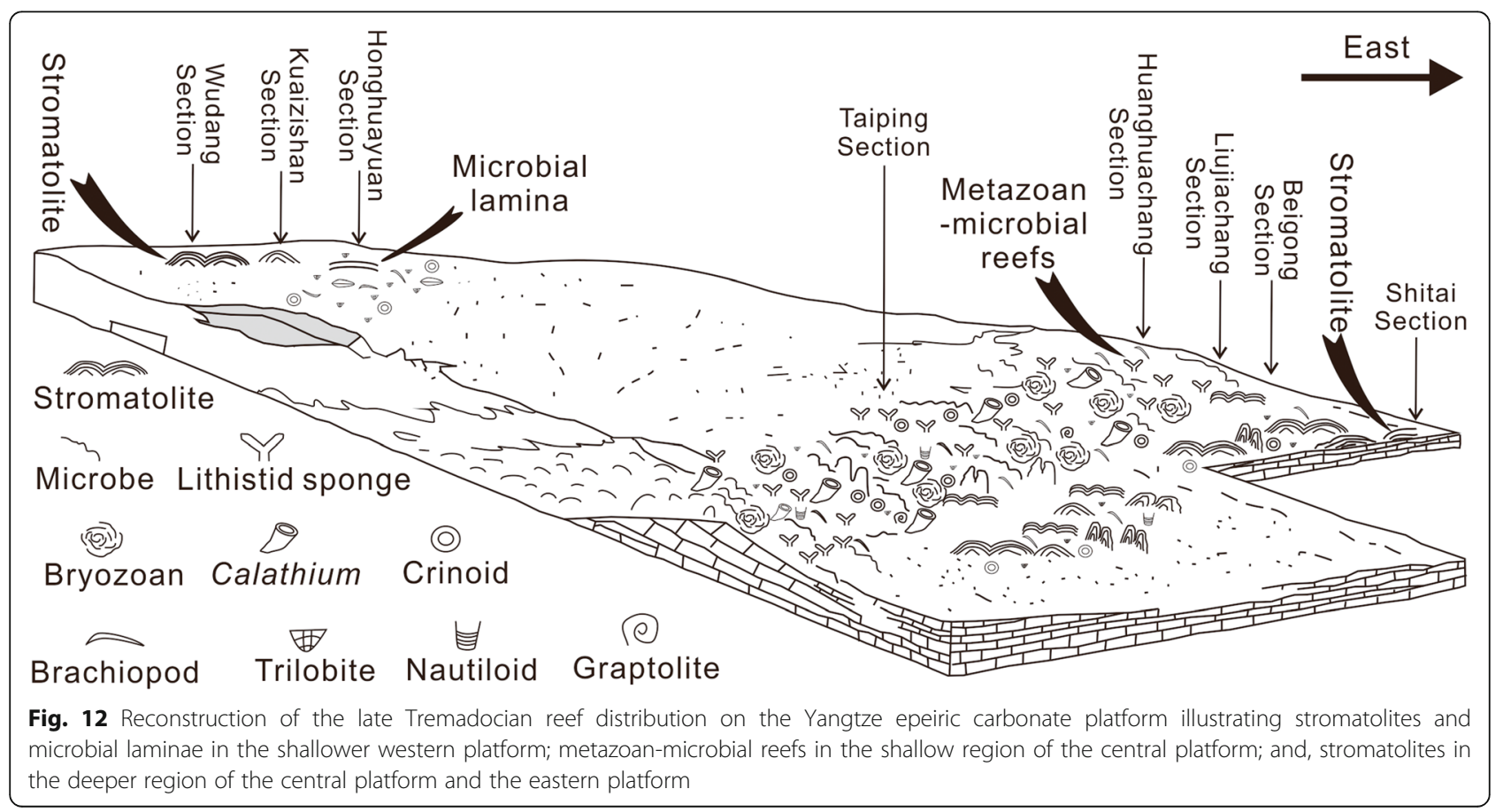




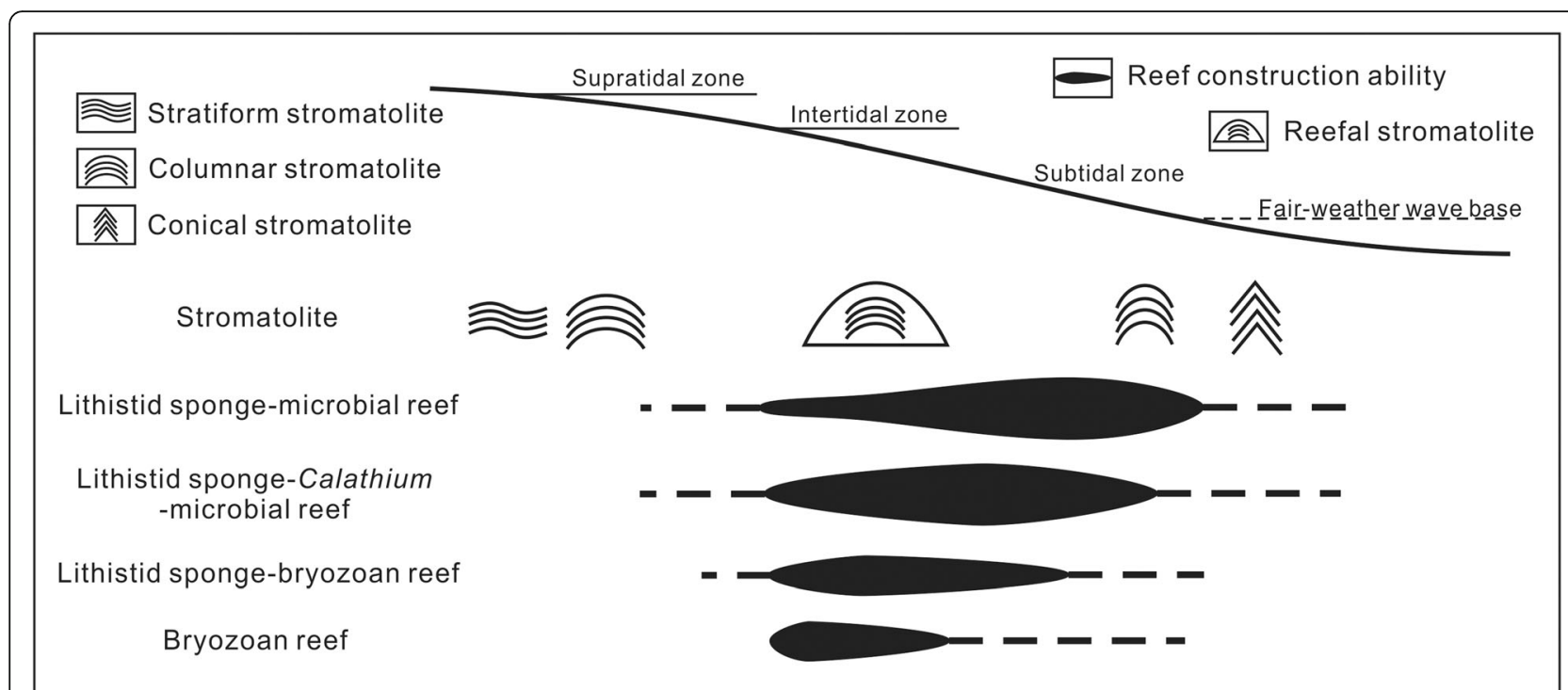

Fig. 13 A simplified sketch of the reef distribution, showing the relative abundance of different types of reefs during the late Tremadocian on the Yangtze Platform

the Fenhsiang Formation at Huanghuachang section. A case study from the Survey Peak Formation in Alberta (Pratt 1995) also revealed lithistid sponges, which might have survived below fair-weather wave base, representing the deepest position of lithistid-bearing reef distribution in the water column. These are evidence of limited oxygen in some deep subtidal settings, leading to scarcity of skeletal reefs there.

As described above, a similar pattern of reef systems on the central Yangtze Platform was reported in the McKelligon Canyon Formation of west Texas (Toomey 1970) and in the Fillmore Formation of Utah (Church 1974). At the dawn of the Ordovician Radiation, these metazoan-bearing reefs thus represent the initial rebound of metazoan-dominated reefs after the Cambrian archaeocyath reef crisis (Li et al. 2015). With a high tolerance to hypoxia (Lee and Riding 2018), lithistid sponges are interpreted to have wider distribution than other skeletal reef-builders and act as pioneers in most skeletal reefs on the Yangtze Platform. The availability of silica might promote the expansion of orchoclad lithistids in shallow environments (Carrera and Botting 2008), however, there is no direct evidence in the material studied here that confirms this hypothesis.

With a subtle difference of environmental preference from anthaspidellids, solitary Calathium and encrustingdomical bryozoans as well as Pulchrilamina replaced lithistid sponges as the main reef-builders when the amelioration in habitat occurred in the upper part of the shallowing upward cycles, which was showed by the examples from the Yangtze Platform of China, Texas and Utah of USA. In the Kindblade Formation in Oklahoma of USA, the hypercalcified sponge Pulchrilamina was a main reef-builder in upper subtidal settings (Toomey and Nitecki 1979), indicating they had competitive superiority for space in these settings, compared with solitary (or low integration) metazoan (e.g. lithistid sponges and Calathium) (Wood 1999).

It is noteworthy that shallow subtidal settings in eastern USA yielded the oldest coral Lichenaria in the widely distributed microbial reefs in ramp settings in Virginia (Bova and Read 1987). As a reef builder, the oldest occurrence of coralomorph Amsassia has reported in the Tremadocian strata from Precordillera of western Argentina (Carrera et al. 2017). Although Amsassia has been described in the Middle-Upper Ordovician from South China and Korea (Lee et al. 2016), there is no reliable record of any reef-building corals on the Yangtze Platform during the Early Ordovician. It is also worth noting that the latest morphological comparisons indicate that Lichenaria actually belong to Amsassia, and Amsassia may represent a calcareous alga, instead of a tabulate (Elias et al. 2020). More work needs to be done to confirm this new insight of origin and evolutionary history of reef-building corals.

\section{Conclusions}

1) The late Tremadocian stromatolites on the Yangtze Platform tend to occur in evaporative facies and deep subtidal settings, while metazoan-dominated reefs are found in the shallow subtidal settings of the central platform. There is no evidence of any keratose spongebearing stromatolite on the platform during this time. 
2) Reef communities were observed in the Huanghuachang section of the central platform: a trend from microbial-dominated to metazoan-dominated with shallowing upward cycles was evident, indicating that the composition of the most reef-builders was mainly driven by water depth.

3) Increasing metazoan competition during the Great Ordovician Biodiversification Event hindered the development of microbial reefs. Sufficient nutrient supply promoted local flourishing of skeletal-dominated reefs in shallow-water settings in the central platform, indicated by the expansion of solitary lithistid sponges and Calathium.

\section{Acknowledgements}

The authors are grateful to You-Dong Chen (Nanjing Institute of Geology and Palaeontology) for preparation of the thin sections. We thank the editors and reviewers ( $M$. Carrera and an anonymous reviewer) for their constructive comments to improve the manuscript. This is a contribution to IGCP Project 653 'The onset of the Great Ordovician Biodiversity Event' and IGCP Project 668 'The stratigraphic and magmatic history of Early Palaeozoic equatorial Gondwana and its associated evolutionary Dynamics'.

\section{Authors' contributions}

JPW, QJL, and YL conceived the idea of the study. JPW, QJL, YYZ, SYY, and YL did the fieldwork sampling, and observed thin sections. JPW, QJL, SK, and YL interpreted the results and wrote the paper. JPW, QJL, SK, YYZ and YL revised the manuscript. All authors read and approved the final manuscript.

\section{Funding}

This study was supported by the China Geological Survey Project (Grant No. DD2019823), the Natural Science Foundation of China (Grant No. 41702003), the Youth Innovation Promotion Association of CAS (2019310), and the special fund for strategic pilot technology Chinese Academy of Sciences (Type B, Grant No. XDB26000000).

\section{Availability of data and materials}

All data generated or analyzed in the current study are available from the corresponding author on reasonable request. The thin sections are deposited in the collections of the Wuhan Centre of Geological Survey and the Nanjing Institute of Geology and Palaeontology.

\section{Declarations}

\section{Competing interests}

The authors declare that they have no competing interests.

\section{Author details \\ 'Wuhan Centre of Geological Survey, China Geological Survey, Wuhan 430205, Hubei Province, China. ${ }^{2}$ Hubei Key Laboratory of Paleontology and Geological Environment Evolution, Wuhan 430205, Hubei Province, China. ${ }^{3}$ State Key Laboratory of Palaeobiology and Stratigraphy, Nanjing Institute of Geology and Palaeontology, Chinese Academy of Sciences, Nanjing 210008, Jiangsu Province, China. ${ }^{4}$ Center for Excellence in Life and Paleoenvironment, Chinese Academy of Sciences, Nanjing 210008, Jiangsu Province, China. ${ }^{5}$ Department of Life Sciences, Halsbury Building, Brunel University, Kingston Lane, Uxbridge UB8 3PH, UK. ${ }^{6}$ Qufu Normal University, Shandong Province, Rizhao 276826, China.}

Received: 5 May 2020 Accepted: 24 February 2021

Published online: 09 March 2021

\section{References}

Adachi, N., Y. Ezaki, and J.B. Liu. 2011. Early Ordovician shift in reef construction from microbial to metazoan reefs. Palaios 26: 106-114.

Adachi, N., Y. Ezaki, and J.B. Liu. 2012a. The oldest bryozoan reefs: An unusual mode of growth for Early Ordovician reefs. Lethaia 14: 14-23.
Adachi, N., Y. Ezaki, and J.B. Liu. 2012b. Early Ordovician stromatoporoid Pulchrilamina spinosa from South China: Geobiological significance and implications for the early development of skeletal-dominated reefs. Paleontological Research 16: 58-68.

Adachi, N., Y. Ezaki, J.B. Liu, and J. Cao. 2009. Early Ordovician reef construction in Anhui Province, South China: A geobiological transition from microbial- to metazoan-dominant reefs. Sedimentary Geology 220: $1-11$.

Adachi, N., J.B. Liu, and Y. Ezaki. 2013. Early Ordovician reefs in South China (Chenjiahe section, Hubei Province): Deciphering the early evolution of skeletal-dominated reefs. Facies 59: 451-466.

BGMRAP (Bureau of Geology and Mineral Resources of Anhui Province). 1987. Regional geology of Anhui Province. Beijing: Geological Publishing House (in Chinese with English Abstract).

Boucot, A.J., X. Chen, and C.R. Scotese. 2009. Global Paleoclimate reconstruction of Phanerozoic. Beijing: Science Press (in Chinese).

Bova, J.A., and J.F. Read. 1987. Incipiently drowned facies within a cyclic peritidal ramp sequence, Early Ordovician Chepultepec interval, Virginia Appalachians. Geological Society of America Bulletin 98: 714-727.

Carrera, M.G., R.A. Astini, and F.A. Gomez. 2017. A lowermost Ordovician tabulate-like coralomorph from the Precordillera of western Argentina: A main component of a reef-framework consortium. Journal of Paleontology 91 (1): 73-85.

Carrera, M.G., and J. Botting. 2008. Evolutionary history of Cambrian spiculate sponges: Implication for the Cambrian evolutionary fauna. Palaios 23: 124-138

Chen, X., and J.Y. Qiu. 1986. Ordovician palaeoenvironmental reconstruction of Yichang area, W. Hubei. Journal of Stratigraphy 10 (1): 1-15 (in Chinese with English Abstract).

Chen, X., Y.D. Zhang, and Y. Li. 1995. Ordovician basin analysis of China. In: Cooper, J.D., M.L. Droser, and S.C. Finney. (Eds.). Ordovician Odyssey: Short Papers of the Seventh International Symposium on the Ordovician System. Pacific Section SEPM 77, Las Vegas: pp. 245-249.

Chen, X.H., L. Zhou, K. Wei, J. Wang, and Z.H. Li. 2012. The environmental index of the rare earth elements in conodonts: Evidence from the Ordovician conodonts of the Huanghuachang section, Yichang area. Chinese Science Bulletin 57: 349-359.

Choh, S.J., J. Hong, N. Sun, S.W. Kwon, T.Y. Park, J. Woo, Y.K. Kwon, D.C. Lee, and D.J. Lee. 2013. Early Ordovician reefs from the Taebaek group, Korea: Constituents, types, and geological implications. Geosciences Journal 17: 139-149.

Church, S.B. 1974. Lower Ordovician patch reefs in western Utah. Brigham Young University, Geology Studies 21: 41-62.

Church, S.B. 2009. Problematic receptaculitid fossils from western Utah and eastern Nevada. Utah Geological Association Publication 38: 55-66.

Church, S.B. 2017. Efficient ornamentation in Ordovician Anthaspidellid sponges. Paleontological Contributions 18: 1-8.

Cuffey, R.J., C.T. Xiao, Z.D. Zhu, S. Nils, and Z.X. Hu. 2013. The world's oldestknown bryozoan reefs: Late Tremadocian, mid-Early Ordovician; Yichang, Central China. In: Ernst, A., P. Schäfer, and J. Scholz. (Eds.). Bryozoan Studies 2010. Lecture Notes in Earth System Sciences 143. Berlin Heidelberg: Springer-Verlag. pp. 13-27.

de Freitas, T., and U. Mayr. 1995. Kilometre-scale microbial buildups in a rimmed carbonate platform succession, Arctic Canada: New insight on Lower Ordovician reef facies. Bulletin of Canadian Petroleum Geology 43: 407-432.

Edwards, C.T., M.R. Saltzman, D.L. Royer, and D.A. Fike. 2017. Oxygenation as a driver of the great Ordovician biodiversification event. Nature Geoscience 10: 925-929.

Elias, R.J., D.J. Lee, and B.R. Pratt. 2020. The "earliest tabulate corals" are not tabulates. Geology 49: G48235.1.

Ethington, R.L. 1977. Notes on the Missouri Ordovician. In: Ethington, R.L., and W.C. Sweet. (Eds.). Guidebook to Field Excursions 2: Ordovician of the Eastern Midcontinent. $3^{\text {rd }}$ International Symposium on the Ordovician System. Columbus, Ohio: Ohio State University; pp. 9-33.

Federov, P. 2003. Lower Ordovician mud mounds from the St. Petersburg region, northwestern Russia. Bulletin of the Geological Society of Denmark 50: 125-137. 
Fischer, A.G. 1965. Fossils, early life, and atmospheric history. Proceedings of the National Academy of Sciences of the United States of America 53: 1213-1215.

Fischer, A.G. 1984. The two Phanerozoic supercycle. In: Berggren, W.A., and J.A. Van Couvering. (Eds.). Catastrophes and Earth History. New Jersey: Princeton University Press; pp. 129-150.

Forsythe, G.T.W. 2003. A new synthesis of Permo-carboniferous phylloid algal reef ecology. AAPG Memoir 78 (83): 171-188.

Grotzinger, J.P. 1989. Facies and evolution of Precambrian carbonate depositional systems: emergence of the modern platform archetype. In: Crevello, P.D., J.L. Wilson, J.F. Sarg, and F.F. Read. (Eds.). Controls on Carbonate Platform and Basin Development. Tusla: SEPM Special Publication 44; pp. 79-106.

Hintze, L.F. 1973. Lower and Middle Ordovician stratigraphic sections in the ibex area, Millard County, Utah. Brigham Young University, Geology Studies 20: 3-36.

Jiang, L., J.P. Wang, Y. Li, and C. Ni. 2014. Stromatolite of the Lower Ordovician Lunshan formation in Shitai, South Anhui Province, East China. Acta Micropalaeontologica Sinica 31: 27-36 (in Chinese with English Abstract).

Kröger, B., A. Desrochers, and A. Ernst. 2017. The reengineering of reef habitats during the great Ordovician biodiversification event. Palaios 32: 584-599.

Kwon, Y.K., D.J. Lee, D.K. Choi, and S.W. Chough. 2003. Lower Ordovician sponge bioherms in the Makkol formation, Taebaeksan Basin, Mideast Korea. Facies 48: 79-90.

Lee, J.H., and R. Riding. 2018. Marine oxygenation, lithistid sponges, and the early history of Paleozoic skeletal reefs. Earth-Science Reviews 181: 98-121.

Lee, M., H. Park, N.V. Tien, S.-J. Choh, R.J. Elias, and D.-J. Lee. 2016. A new species of Amsassia from the Ordovician of Korea and South China: Paleobiological and paleogeographical significance. Acta Geologica Sinica 90: 796-806.

Lehnert, O., M. Keller, and O. Bordonaro. 1998. Early Ordovician conodonts from the southern Cuyania Terrane (Mendoza Province, Argentina). Palaeontologia Polonica 58: 47-65.

Li, Q.J., Y. Li, and W. Kiessling. 2015. Early Ordovician lithistid sponge-Calathium reefs on the Yangtze Platform and their paleoceanographic implications. Palaeogeography, Palaeoclimatology, Palaeoecology 425: 84-96.

Li, Q.J., Y. Li, and W. Kiessling. 2017. The oldest labechiid stromatoporoids from intraskeletal crypts in lithistid sponge-Calathium reefs. Lethaia 50 (1): 140-148

Li, Q.J., M. Sone, O. Lehnert, and L. Na. 2019. Early Ordovician spongebearing microbialites from peninsular Malaysia: The initial rise of metazoans in reefs. Palaeoworld 28 (1-2): 80-95.

Li, Y., S. Kershaw, and X.N. Mu. 2004. Ordovician reef systems and settings in South China before the Late Ordovician mass extinction. Palaeogeography, Palaeoclimatology, Palaeoecology 205: 235-254.

Liu, J.B. 2009. Marine sedimentary response to the great Ordovician biodiversification event: Examples from North China and South China. Paleontological Research 13 (1): 9-21.

Liu, J.B., and R.B. Zhan. 2009. Temporal distribution of diagnostic biofabrics in the Lower and Middle Ordovician in North China: Clues to the Geobiology of the Great Ordovician Biodiversification. Acta Geologica Sinica 83(3): 801-811.

Ma, J.Y., P. Taylor, F.S. Xia, and R.B. Zhan. 2015. The oldest known bryozoan: Prophyllodictya (Cryptostomata) from the lower Tremadocian (Lower Ordovician) of Liujiachang, southwestern Hubei, Central China. Palaeontology 58 (5): 925-934.

Mallela, J. 2007. Coral reef encruster communities and carbonate production in cryptic and exposed coral reef habitats along a gradient of terrestrial disturbance. Coral Reefs 26: 775-785.

Martin, R.E. 1995. Cyclic and secular variation in microfossil biomineralization: Clues to the biogeochemical evolution of Phanerozoic oceans. Global and Planetary Change 11: 1-23.

Martin, R.E. 1996. Secular increase in nutrient levels through the Phanerozoic: Implications for productivity, biomass and diversity of the marine biosphere. Palaios 11: 209-219.
Myrow, P.M., L. Tice, B. Archuleta, B. Clark, J.F. Taylor, and R.L. Ripperdan. 2004. Flat-pebble conglomerate: Its multiple origins and relationship to metre-scale depositional cycles. Sedimentology 51 (5): 973-996.

Payne, J.L., and S. Finnegan. 2006. Controls on marine animal biomass through geological time. Geobiology 4 (1): 1-10.

Peters, S.E., J.M. Husson, and J. Wilcots. 2017. The rise and fall of stromatolites in shallow marine environments. Geology 45 (6): 487-490.

Pratt, B.R. 1995. The origin, biota and evolution of deep-water mud mounds. In: Monty, C.L.V., D.W.J. Bosence, P.H. Bridges, and B.R. Pratt. (Eds.). Carbonate Mud-Mounds: Their Origin and Evolution. International Association of Sedimentologists, Special Publication 23. New York: Wiley; pp. 49-123.

Riding, R. 2006. Microbial carbonate abundance compared with fluctuations in metazoan diversity over geological time. Sedimentary Geology 185: 229-238.

Servais, T., and D.A.T. Harper. 2018. The great Ordovician biodiversification event (GOBE): Definition, concept and duration. Lethaia 51: 151-164.

Servais, T., A.W. Owen, D.A.T. Harper, B. Kröger, and A. Munnecke. 2010. The great Ordovician biodiversification event (GOBE): The palaeoecological dimension. Palaeogeography, Palaeoclimatology, Palaeoecology 294: 99-119.

Taylor, P.D., and C. Sendino. 2010. Latitudinal distribution of bryozoan-rich sediments in the Ordovician. Bulletin of Geosciences 85: 565-572.

Toomey, D.F. 1970. An unhurried look at a lower Ordovician mound horizon, southern Franklin mountains, West Texas. Journal of Sedimentary Petrology 40: 1318-1334.

Toomey, D.F., and M.H. Nitecki. 1979. Organic buildups in the Lower Ordovician (Canadian) of Texas and Oklahoma. Fieldiana: Geology (Chicago) 2: 1-181.

Torsvik, T.H., and L.R.M. Cocks. 2013. New global palaeogeographical reconstructions for the Early Paleozoic and their generation. Geological Society, London, Memoirs 38: 5-24.

Trotter, J.A., I.S. Williams, C.R. Barnes, C. Lécuyer, and R.S. Nicoll. 2008. Did cooling oceans trigger Ordovician biodiversification? Evidence from conodont thermometry. Science 321: 550-554.

Wang, J.P., X.J. Deng, G. Wang, and Y. Li. 2012. Types and biotic successions of Ordovician reefs in China. Chinese Science Bulletin 57: 1160-1168.

Wang, X.F., S.Z. Ni, G.H. Xu, T.M. Zhou, Z.H. Li, L. Xiang, and C. Lai. 1987. Biostratigraphy of the Yangtze gorge area (2): Early Palaeozoic era. Beijing: Geological Publishing House (in Chinese with English Abstract).

Wang, Z.H., S.M. Bergström, and H.R. Lane. 1996. Conodont provinces and biostratigraphy in the Ordovician of China. Acta Palaeontologica Sinica 35: 26-58 (in Chinese with English Abstract).

Webby, B.D. 2002. Patterns of Ordovician reef development. In Phanerozoic reef patterns, ed. W. Kiessling, E. Flügel, and J. Golonka, 129-179. Tulsa: SEPM special publication 72.

Witzke, B.J. 1990. Palaeoclimatic constraints for Palaeozoic palaeolatitudes of Laurentia and Euramerica. In: McKerrow, W.S., and C.R. Scotese. (Eds.). Palaeozoic Palaeogeography and Biogeography. Geological Society of London, Memoir 12, pp. 57-73.

Wood, R. 1993. Nutrients, predation and the history of reef building. Palaios 8: $526-543$.

Wood, R. 1999. Reef evolution. Oxford: Oxford University Press.

Xiao, C.T., M. Li, W. Yang, M.Y. Hu, and C. Li. 2011. Paleoecology of Early Ordovician reefs in the Yichang area, Hubei: A correlation of organic reefs between Early Ordovician and Jurassic. Acta Geologica Sinica 85: 1003-1015.

Yu, S.Y., Q.J. Li, S. Kershaw, Y. Li, Y.Y. Mao, and X.N. Mu. 2020. Microbial reefs in eastern Yangtze Platform, South China Block: The last golden age of stromatolites in the Ordovician. Facies 66 (2): 1-15.

Zhan, R.B., and J.S. Jin. 2007. Ordovician-Early Silurian (Llandovery) Stratigraphy and Palaeontology of the Upper Yangtze Platform, South China. Beijing: Science Press.

Zhang, Y.Y., Q.J. Li, Y. Li, W. Kiessling, and J.P. Wang. 2016. Cambrian to Lower Ordovician reefs on the Yangtze Platform, South China Block, and their controlling factors. Facies 62: 17. https://doi.org/10.1007/s1034 7-016-0466-8. 
Zhen, Y.Y., I. Percival, J.B. Liu, and Y.D. Zhang. 2009. Conodont fauna and biostratigraphy of the Honghuayuan Formation (Early Ordovician) of Guizhou, South China. Alcheringa 33: 257-295.

Zhu, Z.D., M.Y. Hu, B.L. Liu, C.T. Xiao, W. Yang, and X.M. Li. 2006. The EarlyMiddle Ordovician bioherms of China. Beijing: Geological Publishing House (in Chinese).

Zhu, Z.D., B.L. Liu, and X.M. Li. 1993. Pulchrilamina found in Early Ordovician reef at Huanghuachang, Yichang, Hubei. Oil and Gas Geology 14: 304309 (in Chinese with English Abstract).

\section{Publisher's Note}

Springer Nature remains neutral with regard to jurisdictional claims in published maps and institutional affiliations.

\section{Submit your manuscript to a SpringerOpen ${ }^{\odot}$ journal and benefit from:}

- Convenient online submission

- Rigorous peer review

- Open access: articles freely available online

- High visibility within the field

- Retaining the copyright to your article

Submit your next manuscript at $\boldsymbol{\nabla}$ springeropen.com 